Linguagem em (Dis)curso - LemD, v. 8, n. 3, p. 581-612, set./dez. 2008

\title{
O LETRAMENTO ESCOLAR E OS TEXTOS DA DIVULGAÇÃO CIENTÍ́FICA - A APROPRIAÇÃO DOS GÊNEROS DE DISCURSO NA ESCOLA*
}

Roxane Rojo**

\begin{abstract}
Resumo: Neste ensaio, define-se letramento escolar na perspectiva dos letramentos múltiplos e situados e, a partir de uma discussão sobre os textos da divulgação científica, caracterizam-se brevemente, na perspectiva bakhtiniana, alguns dos gêneros discursivos da divulgação científica didatizados na escola (verbetes, artigos, reportagens). Entendendo o processo de apropriação de gêneros discursivos como um aspecto importante das práticas e dos processos de letramento escolar, o ensaio, em sua segunda parte, traz uma análise de como este processo de apropriação dos gêneros da divulgação científica se dá nas salas de aula, a partir de seminários realizados por alunos do Ensino Fundamental II (EFII). Os resultados indicam que, embora muito presentes nos livros e práticas discursivas escolares, os textos da divulgação científica não são efetivamente abordados no ensino, e sua apropriação se faz por imersão, colocando especialmente problemas em relação às linguagens especializadas.

Palavras-chave: letramento escolar; gênero discursivo; divulgação científica.
\end{abstract}

\section{O LUGAR DO LETRAMENTO ESCOLAR NOS LETRA- MENTOS MÚLTIPLOS}

As abordagens mais recentes dos Estudos de Letramento têm apontado para a heterogeneidade das práticas sociais de leitura, escrita e

\footnotetext{
* Agradecemos ao CNPq o apoio a esta pesquisa, configurado no Grupo de Pesquisa certificado pela Unicamp no Diretório CNPq, intitulado Livro Didático de Lingua Portuguesa: Produção, Perfil e Circulação, acrônimo LDP-Properfil, cujos dados e maiores informações podem ser encontradas no site http://homepage.mac.com/rrojo/LDP-Properfil.

** Professora do IEL/UNICAMP. Doutora em Lingüística Aplicada ao Ensino de Línguas. E-mail: <rrojo@terra.com.br>.
} 
uso da língua/linguagem em geral em sociedades letradas e têm insistido no caráter sócio-cultural e situado das práticas de letramento (HEATH, 1983; STREET, 1984, 1995, 2003; BARTON, 1994; BARTON; HAMILTON, 1998; GEE, 1996; PRINSLOO; BREIER, 1996; dentre outros). ${ }^{1}$ Esta posição, como nota Street (2003, p. 77),

implica o reconhecimento dos múltiplos letramentos, que variam no tempo e no espaço, mas que são também contestados nas relações de poder. Assim, os NLS não pressupõem coisa alguma como garantida em relação aos letramentos e às práticas sociais com que se associam, problematizando aquilo que conta como letramento em qualquer tempo-espaço e interrogando-se sobre "quais letramentos" são dominantes e quais são marginalizados ou de resistência. ${ }^{2}$

Voltando-se este artigo para os letramentos escolares e, em especial, para os gêneros de discurso da divulgação científica que circulam nas salas de aula de Ensino Fundamental ( $5^{\mathrm{a}}$ a $8^{\mathrm{a}}$ séries), inserese no campo de investigação dos letramentos "dominantes". Hamilton (2002, p. 4) chama os letramentos dominantes de "institucionalizados" e os distingue dos letramentos locais "vernaculares" (ou autogerados). Entretanto, não os vê como categorias independentes ou radicalmente separadas, mas interligadas. Para a autora, os letramentos dominantes estão associados a organizações formais tais como a escola, as igrejas, o local de trabalho, o sistema legal, o comércio, as burocracias. Caracterizaos como "parte dos discursos especializados incluídos em comunidades de práticas, padronizados e definidos em termos dos propósitos formais da instituição, ao invés de pelos propósitos múltiplos e integrados dos cidadãos e de suas comunidades" (HAMILTON, 2002, p. 4). Os letramentos dominantes prevêem agentes (professores, autores de LD, especialistas) que, em relação ao conhecimento, são valorizados legal e culturalmente, são poderosos na proporção do poder da sua instituição de origem. Já os chamados letramentos "vernaculares" não são

\footnotetext{
${ }^{1}$ Letramento, aqui, é definido como uma grande variedade de práticas de linguagem que envolve, de uma ou de outra maneira, textos escritos (letramentos, no plural).

2 Tradução nossa: "This entails the recognition of multiple literacies, varying according to time and space, but also contested in relations of power. NLS, then, takes nothing for granted with respect to literacy and the social practices with which it becomes associated, problematizing what counts as literacy at any time and place and asking 'whose literacies' are dominant and whose are marginalized or resistant" (STREET, 2003, p. 77).
}

ROJO - O letramento escolar e os textos da divulgação científica... 
regulados, controlados ou sistematizados por instituições ou organizações sociais, mas têm sua origem na vida cotidiana, nas culturas locais. Como tal, freqüentemente são desvalorizados ou desprezados pela cultura oficial e são práticas de resistência ou táticas, no sentido de Certeau (1994).

Os Estudos de Letramento têm se voltado em especial para os letramentos locais ou vernaculares, de maneira a dar conta da heretogeneidade das práticas não valorizadas e, portanto, pouco investigadas. No entanto, cabe também, na contemporaneidade, uma revisão dos letramentos dominantes, em especial dos letramentos escolares, por diversas razões.

Em primeiro lugar, por causa de como se apresenta o mundo contemporâneo. Podemos dizer que, efeito da globalização, o mundo mudou muito nas últimas duas décadas. Em termos de exigências de novos letramentos, é especialmente importante destacar as mudanças relativas aos meios de comunicação e à circulação da informação. $\mathrm{O}$ surgimento e a ampliação contínua de acesso às tecnologias digitais da comunicação e informação (computadores pessoais, mas também celulares, tocadores de mp3, TVs digitais, entre outras) implicaram pelo menos três mudanças que ganham importância na reflexão sobre os letramentos socialmente requeridos:

a) a intensificação vertiginosa e a diversificação da circulação da informação nos meios de comunicação analógicos e digitais, que, pois isso mesmo, distanciam-se hoje dos meios impressos, muito mais morosos e seletivos, implicando, segundo alguns autores (CHARTIER, 1997; BEAUDOUIN, 2002), mudanças significativas nas maneiras de ler, de produzir e de fazer circular textos nas sociedades;

b) a diminuição das distâncias espaciais - tanto em termos geográficos, por efeito dos transportes rápidos, como em termos culturais e informacionais, por efeito da mídia digital, desenraizando as populações e desconstruindo identidades, e a diminuição das distâncias temporais ou a contração do tempo, determinadas pela velocidade sem precedentes, pela quase instantaneidade dos transportes, da informação, dos produtos 
culturais das mídias, características que também colaboram para mudanças nas práticas de letramentos;

c) a multissemiose que as possibilidades multimidiáticas e hipermidiáticas do texto eletrônico trazem para o ato de leitura: já não basta mais a leitura do texto verbal escrito - é preciso colocá-lo em relação com um conjunto de signos de outras modalidades de linguagem (imagem estática, imagem em movimento, fala, música) que o cercam, ou intercalam ou impregnam; esses textos multissemióticos extrapolaram os limites dos ambientes digitais e invadiram também os impressos (jornais, revistas, livros didáticos).

Por outro lado, a escola - em especial a pública - também mudou bastante nos últimos 50 anos no Brasil, mas não na mesma direção. Buscou-se - e atingiu-se, na década de 90 - a universalização do acesso à educação pública no Ensino Fundamental, e hoje se busca a mesma ampliação e universalização de acesso no Ensino Médio. Claro está, acesso não quer dizer permanência e nem qualidade de ensino. Ainda assim, a ampliação de acesso tem impactos visíveis nos letramentos escolares: o ingresso de alunado e de professorado das classes populares nas escolas públicas trouxe para os intramuros escolares letramentos locais ou vernaculares antes desconhecidos e ainda hoje ignorados. Isso cria uma situação de conflito entre práticas letradas valorizadas e não valorizadas, que beira a situação diglóssica, como apontam os trabalhos de Heath (1983) e Kleiman (1995, 1998), por exemplo.

Hamilton (2002, p. 8) aponta para o fato de que muitos dos letramentos, que são influentes e valorizados na vida cotidiana das pessoas e que têm ampla circulação, são também ignorados e desvalorizados pelas instituições educacionais: "não contam como letramento "verdadeiro"'. Da mesma maneira, as redes sociais e informais que sustentam essas práticas letradas permanecem desconhecidas e apagadas nas escolas.

Essas mudanças fazem ver a escola de hoje como um universo de letramentos múltiplos e muito diferenciados, cotidianos e institucionais, valorizados e não valorizados, locais e globais, vernaculares e autônomos, sempre em contato e em conflito, sendo alguns ignorados e apagados e outros constantemente enfatizados. 
Nessas circunstâncias, o que significa trabalhar a leitura e a escrita para o mundo contemporâneo? Ou, como diz Hamilton (2002), como esboçar políticas de letramento "ao longo da vida" que realmente sustentem e desenvolvam os recursos, processos e metas que existem e são requeridos na vida cidadã?

Um dos objetivos principais da escola é justamente possibilitar que seus alunos possam participar das várias práticas sociais que se utilizam da leitura e da escrita (letramentos) na vida da cidade, de maneira ética, crítica e democrática. Para fazê-lo, é preciso que a educação lingüística leve em conta hoje:

a) os multiletramentos ou letramentos múltiplos, também de maneira ética e democrática, deixando de ignorar ou apagar os letramentos das culturas locais de seus agentes (professores, alunos, comunidade escolar) e colocando-os em contato com os letramentos valorizados e institucionais; como diria Souza Santos (2005), assumindo seu papel cosmopolita; ${ }^{3}$

b) os letramentos multissemióticos exigidos pelos textos contemporâneos, ampliando a noção de letramento para o campo da imagem, da música, das outras semioses e sistemas de signos que não somente a escrita alfabética, como já prenunciava, por exemplo, a noção de "numeramento"; o conhecimento de outros meios semióticos está ficando cada vez mais necessário no uso da linguagem, tendo em vista os avanços tecnológicos: as cores, as imagens, os sons, o design etc., que estão disponíveis na tela do computador e em muitos materiais impressos, que têm exigido outros letramentos, por exemplo, o letramento visual e que "têm transformado o letramento tradicional (da letra) em um tipo de letramento insuficiente para

\footnotetext{
${ }^{3}$ Souza Santos (2005) aponta para a "globalização ou coligação contra-hegemônica", que não se baseia no incremento e na proteção do local enraizado - embora não negue seu valor estratégico, designando-o como "localização contra-hegemônica" -, mas no que ele chama de as "iniciativas, organizações e movimentos integrantes do cosmopolitismo e do patrimônio comum da humanidade, com vocação transnacional", mas ancoradas em "lutas locais concretas", dentre elas, a escola. [...] "O global acontece localmente. É preciso fazer com que o local contra-hegemônico também aconteça globalmente" (p. 74).
} 
dar conta daqueles necessários para agir na vida contemporânea" (MOITA-LOPES; ROJO, 2004, p. 38);

c) os letramentos críticos e protagonistas requeridos para o trato ético dos discursos em uma sociedade saturada de textos e que não pode lidar com eles de maneira instantânea, amorfa e alienada; como afirmam Moita-Lopes \& Rojo (2004, p. 37-38), é preciso levar em conta

o fato de que a linguagem não ocorre em um vácuo social e que, portanto, textos orais e escritos não têm sentido em si mesmos, mas interlocutores (escritores e leitores, por exemplo) situados no mundo social com seus valores, projetos políticos, histórias e desejos constroem seus significados para agir na vida social. Os significados são contextualizados. Essa compreensão é extremamente importante no mundo altamente semiotizado da globalização, uma vez que possibilita situar os discursos a que somos expostos e recuperar sua situacionalidade social ou seu contexto de produção e interpretação: quem escreveu, com que propósito, onde foi publicado, quando, quem era o interlocutor projetado etc. Tal teorização tem uma implicação prática, porque possibilita trabalhar em sala de aula com uma visão de linguagem que fornece artifícios para os alunos aprenderem, na prática escolar, a fazer escolhas éticas entre os discursos em que circulam. Isso possibilita aprender a problematizar o discurso hegemônico da globalização e os significados anti-éticos que desrespeitem a diferença (ênfase dos autores).

Essas novas exigências que o mundo contemporâneo coloca para a escola, portanto, vão multiplicar enormemente as práticas letradas e os textos de diversos gêneros que nela devem circular e ser abordadas(os). O letramento escolar tal como o conhecemos, voltado principalmente para as práticas de leitura e escrita de textos em gêneros escolares (anotações, resumos, resenhas, ensaios, dissertações, descrições, narrações e relatos, exercícios, instruções, questionários, dentre outros) e para alguns poucos gêneros escolarizados advindos de outras esferas (literária, jornalística, publicitária) não será suficiente para atingir as três metas enunciadas anteriormente. Será necessário ampliar e democratizar 
tanto as práticas e eventos de letramento que têm lugar na escola como o universo de textos e gêneros que nela circulam.

Neste artigo, vamo-nos centrar em práticas e eventos de letramento típicos da escola, que colocam em circulação textos em gêneros da divulgação científica e didáticos (verbetes, artigos de divulgação científica, relatos históricos - nos livros didáticos - e seminários neles baseados), reconhecendo sempre a necessidade de ampliação e de democratização de práticas/eventos de letramento e do universo de textos em gêneros diversos em circulação na escola. Abordaremos esses textos e práticas/eventos de letramento de maneira a verificar como as práticas de sala de aula os colocam em circulação, como os abordam e qual a apropriação que os estudantes deles fazem, discutindo também em que medida este campo específico dos multiletramentos - o trato dos textos da divulgação científica e escolares - dialoga, nas práticas escolares, com os letramentos locais, com as outras semioses e com o protagonismo crítico.

\section{OS GÊNEROS DA DIVULGAÇÃO CIENTÍFICA: DE ONDE VÊM E COMO SÃO}

Iniciemos pela caracterização de nosso objeto de estudo, os textos de divulgação científica e didáticos, para, na próxima seção, enfocarmos suas formas de (re)produção na esfera escolar.

Por várias ordens de razão - mudanças sócio-históricas, interesse na qualificação dos trabalhadores, mudanças na dinâmica política e nas classes dominantes - a ciência foi um dos bens culturais - assim como as artes e os ofícios - que entraram na disputa social como bens cobiçados a partir do final da Idade Média. A própria idéia de di-vulgação, isto é, a ação de dar ao vulgo (à plebe, aos pobres, aos trabalhadores, aos que falam a língua vulgar - o povo) os bens do conhecimento, nasce desse movimento de acesso sucessivo das massas aos bens culturais valorizados, patronizada pelos intelectuais da Revolução Francesa - os iluministas que devem levar as luzes (da ciência) ao século XVIII. Os textos e discursos de divulgação científica e didáticos surgem justamente dessa vontade política: dar ao vulgo os bens culturais da ciência e do 
conhecimento. No século XVII, pela pena de Rabelais, escreve Gargantua na carta a seu filho Pantagruel um novo e irreverente programa de estudos que dele faria uma imensa enciclopédia viva:

Entendo e quero que aprendas perfeitamente as línguas [...]. Que não haja história de que não tenhas memória presente [...]. Das artes liberais dar-te-ei a sentir o gosto logo de pequeno [...]. ${ }^{4} \mathrm{E}$ quanto ao conhecimento dos fatos da natureza, quero que te entregues com curiosidade, que não haja mar, rio ou fronteira de que não conheças os peixes; todos os pássaros do ar, todas as árvores, arbustos e frutíferas das florestas, todas as ervas da Terra, todos os metais escondidos no ventre dos abismos, todas as pedrarias do oriente e do sul, que nada te seja desconhecido. Depois, revisita cuidadosamente os livros dos médicos gregos, árabes e latinos, sem esquecer os talmudistas e cabalistas e, por anatomias freqüentes, adquire perfeito conhecimento desse outro mundo que é o homem. (Pantagruel, VIII: 134-135, http://www.educ.fc.ul.pt/hyper/enciclopedia/cap2p3/encbar.ht $\mathrm{m}$, acesso em 05/05/2008)

Esses bens culturais foram disputados pelos homens livres, pelos padres da Igreja, pela burguesia, pelos iluministas e pelos trabalhadores. Ao final da chamada Idade Moderna, tínhamos já, em boa parte do Ocidente, uma situação em que todas as classes têm acesso à escolarização - inclusive, como mecanismo de disciplina(riza)ção dos "bárbaros" -, que passa a ser obrigatória e universal. Em princípio, todos devem ter acesso à escola obrigatória e, logo, aos conhecimentos científicos selecionados para compor o currículo escolar.

Desde sempre, as compilações de textos didáticos acompanharam o ensino da Filosofia, da História, das sete Artes Liberais; além disso, a vontade de divulgar os achados da ciência fora da escola, ao povo ou ao "homem do mundo", data do "século das luzes" - o século XVIII. A ação de maior impacto foi, justamente, a organização da Enciclopédia, por Diderot e d'Alembert, empreendimento que tomou de seus

\footnotetext{
${ }^{4}$ Eram sete as Artes Liberais - o Trivium (Gramática, Retórica e Dialética ou Lógica) e o Quadrivium (Aritmética, Geometria, Música e Astronomia).
}

ROJO - O letramento escolar e os textos da divulgação científica... 
organizadores e colaboradores mais de vinte anos e resultou em 28 volumes, com verbetes sobre temas e conceitos científicos, organizados pela primeira vez em ordem alfabética, dando origem à enciclopédia como hoje a conhecemos.

A Enciclopédia foi editada com dificuldades. 5 Duas vezes foi proibida e ficou suspensa durante oito anos. Começada em 1751, somente foi concluída em 1772. Difundiu popularizando as idéias de liberdade individual; liberdade de pensar, escrever e publicar; liberdade comercial e industrial; combate às idéias religiosas, consideradas um obstáculo para a liberdade; combate ao absolutismo político. Logo, foi perseguida e proibida pela Igreja e pelos soberanos. ${ }^{6}$

Assim, a Enciclopédia inaugura uma nova maneira de fazer circular as idéias científicas e coloca à disposição do povo um enorme conjunto de textos organizados para divulgação. Com isso, consolidam-se dois gêneros de discurso muito presentes na escola e no ensino: a própria enciclopédia/dicionário como hoje a/o conhecemos e o verbete. ${ }^{7}$

Pela primeira vez, como vimos, a Enciclopédia organiza seus verbetes em ordem alfabética. Essa opção não é por acaso: Diderot e D'Alembert pretendem fornecer uma visão geral dos achados da ciência, uma espécie de mapeamento interdisciplinar, livre da compartimentação das disciplinas. Escreve D’Alembert que organizar os verbetes (artigos) da Enciclopédia:

\footnotetext{
${ }^{5}$ A Enciclopédia e suas idéias - de igualdade e fraternidade entre os homens do mundo, de liberdade tiveram um papel importante na eclosão da Revolução Francesa. As novas idéias difundiram-se não só na Europa, mas em toda a América. Apesar da rigorosa censura, as obras e os autores proibidos (a própria Enciclopédia, Montesquieu, Voltaire, Rousseau) foram entrando clandestinamente nas colônias espanholas. Sua influência também se exerceu no Brasil e manifestou-se claramente na Inconfidência Mineira (1789).

${ }^{6}$ Tendo começado a ser editada em Paris em 1751, logo após a edição em Janeiro de 1752 do segundo volume, será publicado, em 7 de Fevereiro do mesmo ano, um decreto que ordena a suspensão da publicação da obra, acusada de conter "máximas tendentes a destruir a autoridade real, a estabelecer o espírito de independência e de revolta e, sob termos obscuros e equívocos, revelar os fundamentos do erro, da corrupção dos costumes, da irreligião e da impiedade" (cit., in Larousse, 1866: XXV). Graças à proteção de alguma nobreza esclarecida, nomeadamente Mme. de Pompadour e Mr. de Malesherbes, a publicação da obra irá vencendo todos os obstáculos (principalmente, a condenação papal, em 3 de Setembro de 1759) e, em 1765, já estão editados os 28 volumes que a compõem.

7 Verbete é como estaremos chamando cada uma das entradas da Enciclopédia. Portanto, neste texto, entrada e verbete são usados como sinônimos.
} 
Consiste em reuni-los no mais pequeno espaço possível e, por assim dizer, em colocar o filósofo acima desse vasto labirinto num ponto de vista suficientemente elevado para que ele possa perceber em simultâneo as principais ciências e artes; ver num relance os objetos das suas especulações e as operações que pode fazer sobre esses objetos; distinguir os ramos gerais dos conhecimentos humanos, os pontos que os separam e os unem e entrever mesmo algumas estradas secretas que os aproximam. É uma espécie de mapamundi que deve mostrar os principais países, a sua posição e dependência mútua, o caminho em linha reta que vai de um a outro; caminho freqüentemente obstruído por mil obstáculos que não se deixam conhecer pelos habitantes e viajantes de cada país e que só em cartas particulares muito detalhadas poderiam ser mostrados. Essas cartas particulares são os diferentes artigos da Encyclopédie e a Árvore ou Sistema figurado será o mapamundi. (L'Encyclopédie, Discours Préliminaire: 59-60, retirado de http://www.educ.fc.ul.pt/hyper/enciclopedia/cap2p5/tar-plan. $\mathrm{htm}$, acessado em 28/06/06, ênfase adicionada)

Assim, não organizam os livros da Enciclopédia por ciência ou temas científicos disciplinares, mas pela aleatória ordem alfabética. Mas, ao escolherem esta ordem, criam o problema de como relacionar os conhecimentos entre si. 8 Com isso, acabam inventando a "linkagem" ou remissão dentro dos verbetes que compõem a Enciclopédia. De certa forma, a Enciclopédia é o primeiro hipertexto. Toda remissão (por exemplo, as notas de rodapé, boxes e os hiperlinks) supõe a participação do leitor. Mais ela é feita com o objetivo de facilitar a exploração do edifício textual. As remissões são, em última análise, protocolos de leitura, "itinerários" de viagem que cabe ao autor/editor sugerir e colocar à disposição do leitor. Mas é o leitor que vai ou não atualizar essas possibilidades.

Um primeiro tipo de remissão na Enciclopédia, que poderíamos designar por classificatória ou integradora, consiste simplesmente em indicar "o nome da ciência à qual a entrada pertence" (L’Encyclopédie,

\footnotetext{
${ }^{8}$ No início do verbete encyclopédie, Diderot diz mesmo que a palavra enciclopédia, na sua raiz etimológica, significa encadeamento de conhecimentos.
}

ROJO - O letramento escolar e os textos da divulgação científica... 
Discours Préliminaire: 71, retirado de http://www.educ.fc.ul.pt/hyper/ enciclopedia/cap2p5/tar-cons.htm, acesso em 28/06/06). Nesse sentido, logo após o título que identifica o assunto fundamental da entrada ou verbete, é colocado (entre parênteses) o nome da ciência que se ocupa desse assunto. Uma vez identificada a ciência de referência, o verbete pode ser facilmente situado no quadro dos conhecimentos humanos (Sistema Figurado) apresentado em apêndice à Enciclopédia.

Um segundo tipo de remissão, interna ao verbete e hipertextual, consiste na "ligação da entrada com outras na mesma ciência ou numa ciência diferente" (L’Encyclopédie, Discours Préliminaire: 71, retirado de www.educ.fc.ul.pt/hyper/enciclopedia/cap2p5/tar-cons.htm, acesso em 28/06/06). A remissão é então feita ou no fim do verbete: "veja tal ou tal outra entrada", ou no interior do próprio texto da entrada, sempre sob a forma de palavras em maiúsculas, assim como os links nos hipertextos da Internet estão sinalizados em azul. Por exemplo, a entrada Basilic (Enciclopédia, II: 116), remete o leitor, em primeiro lugar, para História Natural, Botânica. ${ }^{9}$ Em seguida, no fim do verbete Basilic, é feita uma remissão sob a forma: veja PLANTA (Enciclopédia, II: 116). Na entrada Biblioteca, a remissão aparece no interior do texto, sob a forma falaremos desta ordem no artigo CATÁLOGO (Enciclopédia, II: 228). Na entrada Cassiopéia, há diversas remissões a outros verbetes da enciclopédia, em diferentes momentos do texto, tais como veja CONSTELAC $\tilde{A O}$, veja COMETA e ESTRELA (Enciclopédia, II: 747).

Assim, o verbete é um texto, em um gênero específico da esfera de divulgação científica, não muito longo, organizado por um especialista no campo científico, que visa transmitir conceitos de diversas áreas do conhecimento humano. Os verbetes podem pertencer tanto a uma enciclopédia quanto a um dicionário comum da língua ou a um dicionário especializado. $\mathrm{O}$ especialista busca transmitir ao leigo (ao nãoespecialista) um conceito científico de maneira relativamente simples e compreensível. Por isso, simplifica e abrevia a linguagem científica sobre o assunto. Logo, os temas dos verbetes são os conceitos ou noções elaborados pelas ciências, mas simplificados.

Quem consulta uma enciclopédia ou um dicionário é, em geral, o não-especialista, aquele que precisa da informação para estudar ou para

\footnotetext{
${ }^{9}$ Manjericão.
} 
qualquer outra finalidade, o leigo no assunto. $\mathrm{O}$ gênero verbete, em sua forma textual, reflete esse contexto de comunicação: é breve (o máximo possível) e apresenta uma definição principal atualizada do termo em questão - a definição da ciência (ou da arte) de referência -, seguida de algumas outras definições, menos científicas e mais populares, se houver, e de alguns contextos em que se usa a palavra.

No que se refere a estilo, essa definição "simples" ainda utilizará o vocabulário das ciências - a linguagem especializada - e, logo, não será tão "simples" assim. Em primeiro lugar, certos enfoques das ciências pretendem tratar de "verdades universais; eternas". Assim, as definições sempre aparecerão em um presente eterno (por meio da ausência dos verbos, ou seja, sob formas nominais, ou da presença de verbos no chamado "presente de definição"). Por outro lado, não é fácil simplificar a linguagem especializada das ciências e, por isso, o verbetista precisará sempre remeter a novos conceitos, fazendo as remissões ou linkagens que já comentamos.

O verbete é, pois, um gênero clássico da divulgação científica, e o primeiro a surgir nessa esfera de circulação de textos. Hoje, entretanto, não precisamos nos limitar ao que enciclopédias e dicionários oferecem no campo do conhecimento científico. Uma vez que as metas modernas e burguesas do Iluminismo foram, ao menos em parte, alcançadas, hoje encontramos, nas salas de aula, nas bancas de jornais, na Internet e também nas bibliotecas, textos (artigos, reportagens, resenhas, resumos) de divulgação científica confiáveis e atualizados, publicados em diversos veículos.

Assim, a divulgação científica - nascida com o Enciclopedismo continua sendo produzida por cientistas para divulgar conhecimento entre os leigos da forma mais abrangente possível. ${ }^{10}$ Logo, podemos dizer que a esfera de produção dos gêneros artigo/reportagem/notícia/nota de divulgação científica é a esfera científica - as mais conhecidas revistas desse gênero possuem artigos escritos por cientistas e/ou são idealizadas por órgãos de fomento à pesquisa no país - e sua esfera de circulação é a jornalística - os veículos de divulgação se propõem a alcançar cada vez

${ }^{10}$ Ou por jornalistas especializados.

ROJO - O letramento escolar e os textos da divulgação científica... 
mais pessoas e, por isso, as revistas de divulgação são vendidas em bancas e também disponibilizadas on line. ${ }^{11}$

Como é impossível que os autores (em geral, cientistas) saibam de antemão quem lerá o artigo escrito por eles, seu leitor é idealizado, baseado em pesquisas sobre quem compra/assina/lê a revista. Podemos chamar esse leitor desconhecido, mas suposto, de leitor-modelo. Por exemplo, a revista Ciência Hoje declara que tem intenção de falar sobre ciência para a população comum, a sociedade em geral e, particularmente, professores e alunos do ensino médio e superior. Mas o leitor-modelo em outros veículos é mais amplo e variado, menos especializado, constituído por uma fatia mais ampla da população. Em muitos casos, os artigos podem estar assinados por cientistas, mas também podem ser elaborados por jornalistas especializados em divulgação científica e aparecerem assinados ou não.

Assim, não podemos confundir divulgação científica com jornalismo cientifico ou de curiosidades científicas, que possui características próximas às da divulgação científica, se pensarmos nos temas, mas que se distancia dela quando levamos em conta sua esfera de produção, que é jornalística e não científica. É o caso de Revistas como Super Interessante ou Galileu. O próprio estilo dos textos é diferente, pois há uma menor preocupação com o rigor científico, se comparado com o que acontece com os textos de divulgação científica.

Portanto, podemos distinguir três esferas de produção principais para os textos da ciência:

a) os discursos primários, isto é, aqueles que os cientistas escrevem para seus colegas e que falam sem reservas a linguagem das ciências, publicados nas revistas especializadas e falados nas conferências;

b) os discursos de divulgação científica, com diferentes níveis de especialização, destinados a leitores mais ou menos especializados, escritos por cientistas com a intenção de atingir

\footnotetext{
${ }^{11}$ Chamamos veículo ou suporte as formas de publicação onde os textos circulam. No caso dos textos de divulgação científica são exemplos de suporte: revistas especializadas; colunas, seções ou editorias de jornais, documentários em vídeo, revistas on-line etc.
} 
público mais amplo, ou por jornalistas especializados em jornalismo científico;

c) os discursos didáticos, que mais que divulgar achados científicos, destinam-se a ensinar os alunos certos conteúdos científicos; são escritos, em geral, por professores e seu leitormodelo é um estudante; por isso, o texto inclui um número maior de explicações, além de exercícios para assimilação, revisão, avaliação. ${ }^{12}$

Nos gêneros da divulgação científica (artigos, reportagens), quando há diferenças na esfera de produção e circulação, quando os autores e leitores-modelo são diferentes, os textos também vão refletir, no modo como estão escritos, essas diferenças, pois há certos mecanismos textuais que permitem ao autor dirigir-se ao leitor da maneira que julgar mais adequada ao leitor-modelo que tem um mente: ${ }^{13}$

a) se for um leitor leigo, que o autor julga saber pouco sobre o assunto, ele escolherá um linguajar mais cotidiano, inclusive gírias; evitará a linguagem científica especializada, ou, se a usar, buscará explicar e exemplificar em linguagem cotidiana os termos; procurará dirigir-se diretamente ao leitor, como se estivesse interagindo numa conversa;

b) se for um leitor relativamente especializado, que o autor julga ter certo conhecimento acumulado sobre o assunto, o autor adotará um outro estilo: usará a linguagem especializada de sua ciência e deixará de explicar os conceitos que julga já conhecidos, definindo apenas os conceitos mais relevantes para o tema do texto; exemplificará menos ou o fará por meio de diagramas, gráficos, infográficos; exporá seu conteúdo sem interagir diretamente com o leitor, durante quase todo o texto.

\footnotetext{
12 Ver Grillo (2006) a respeito.

13 A descrição aqui esboçada é necessariamente programática e superficial, pelas restrições de espaço de que dispomos, mas será útil posteriormente na análise dos exemplos de seminários de alunos.
}

ROJO - O letramento escolar e os textos da divulgação científica... 
Vemos nesses mecanismos de textualização o estilo de autor. Os estilos de autor podem variar bastante, de acordo com a avaliação que esse faz de seus leitores-modelo. Esses usos da língua já fazem parte do estilo de gênero de divulgação científica, aparecendo tanto em verbetes como em artigos, reportagens e notas.

Finalmente, cabe lembrar que os gêneros modernos e pósmodernos da divulgação científica que se valem das publicações jornalísticas para circular, tais como os artigos, reportagens e notas, são também multissemióticos e hipertextuais, mas de uma maneira diversa da dos verbetes. Em primeiro lugar, apresentam recursos e linguagens visuais e verbais. Os recursos visuais são a forma de diagramação na página texto cheio ou texto em colunas -; a presença de boxes, legendas e destaques e de ilustrações de diferentes tipos (paratextos). Os recursos verbais são o texto e suas subdivisões - título, introdução (olho), texto propriamente dito, subtítulos, textos dos boxes e das legendas.

Boxes, legendas, destaques trazem uma informação paratextual complementar ao texto verbal. Pode ser uma definição que o autor não quer encaixar no corpo do texto, porque não cabe no desenvolvimento do tema, ou uma curiosidade sobre o tema, sugestões para leitura complementar, dados sobre o autor do artigo etc. Os boxes, legendas e destaques são também importantes como elementos hipertextuais de linkagem ou remissão. Essas características hiper e paratextuais importam para o modo como se lê o texto, ou seja, para as práticas de letramento que sobre ele se exercem em eventos específicos.

Também as características multissemióticas desses gêneros impactam as práticas/eventos de letramento e de leitura. Em primeiro lugar, há diferentes tipos de ilustração: algumas, simplesmente ilustram ou exemplificam, tornando o texto menos monótono; outras acrescentam maiores informações. Outras ainda acrescentam informações novas que podem ser decisivas para a compreensão do texto, por exemplo, os gráficos e infográficos. ${ }^{14}$

\footnotetext{
14 "Infografia ou infográficos são representações visuais de informação ou conhecimento. Esses gráficos são usados onde a informação precisa ser explicada de forma mais dinâmica, como em mapas, jornalismo e manuais técnicos, educativos ou científicos" (http://pt.wikipedia.org /wiki/Infográfico, acessado em 16/07/2006).
} 
Ao lermos uma ilustração do tipo infográfico, trabalhamos, ao mesmo tempo, com imagens e textos, com diferentes tipos de linguagem, para construir um esquema mental de um processo. Aliás, é exatamente disso que se trata em infográficos: neles, costumam ser utilizados esquemas teóricos simplificados de processos muito mais complexos. Assim, se apenas o texto permanecesse, os leitores teriam de imaginar esse esquema, o que não seria tarefa nada fácil.

Logo, mais do que apenas apresentar imagem e texto, podemos dizer que nos infográficos esses dois elementos se complementam, são interligados. Infográficos e gráficos complementam, explicam e esquematizam novas informações em relação ao que é dito no texto principal. Certamente podemos transformar o infográfico apenas em texto, mas será que ele seria agradável e simples de ser lido?

Por outro lado, os textos circundantes (legendas, boxes, texto principal) trazem informações complementares aos (info)gráficos.

Verbetes (definições), (fragmentos de) artigos, reportagens e notas de divulgação científica compõem boa parte dos textos que integram as práticas/eventos de letramento escolar seja nos manuais didáticos, nos paradidáticos, nas obras de referência (atlas, gramáticas, dicionários, enciclopédias), ou nos materiais de pesquisa presentes em veículos e suportes variados, impressos e digitais, tais como revistas, seções de jornais, revistas on-line, sites e portais, dentre outros.

\section{LETRAMENTOS, LIVRO DIDÁTICO E OS GÊNEROS DE DIVULGAÇÃO CIENTÍFICA NAS PRÁTICAS DE SALA DE AULA}

Para além da presença massiva desses gêneros da divulgação científica nos livros escolares das disciplinas de Ciências, História, Geografia e Matemática do EF, eles também se encontram bastante presentes nos LD de Português (LDP). Por exemplo, nas 36 coleções de LDP avaliadas no PNLD/2005, os textos em gêneros da divulgação científica constituem $18 \%$ das coletâneas, ou seja, cerca de um quinto do 
conjunto de textos presentes nos LDP. 15, 16 Não estamos aqui falando do discurso autoral, mas dos textos que se apresentam como objetos para leitura, modelo de produção ou suporte de análise gramatical.

Os 144 volumes destinados a Língua Portuguesa analisados nessa edição do PNLD apresentavam em suas coletâneas 13.828 textos - numa média de 96 textos por volume - dos quais 2.488 pertenciam à esfera de divulgação científica.

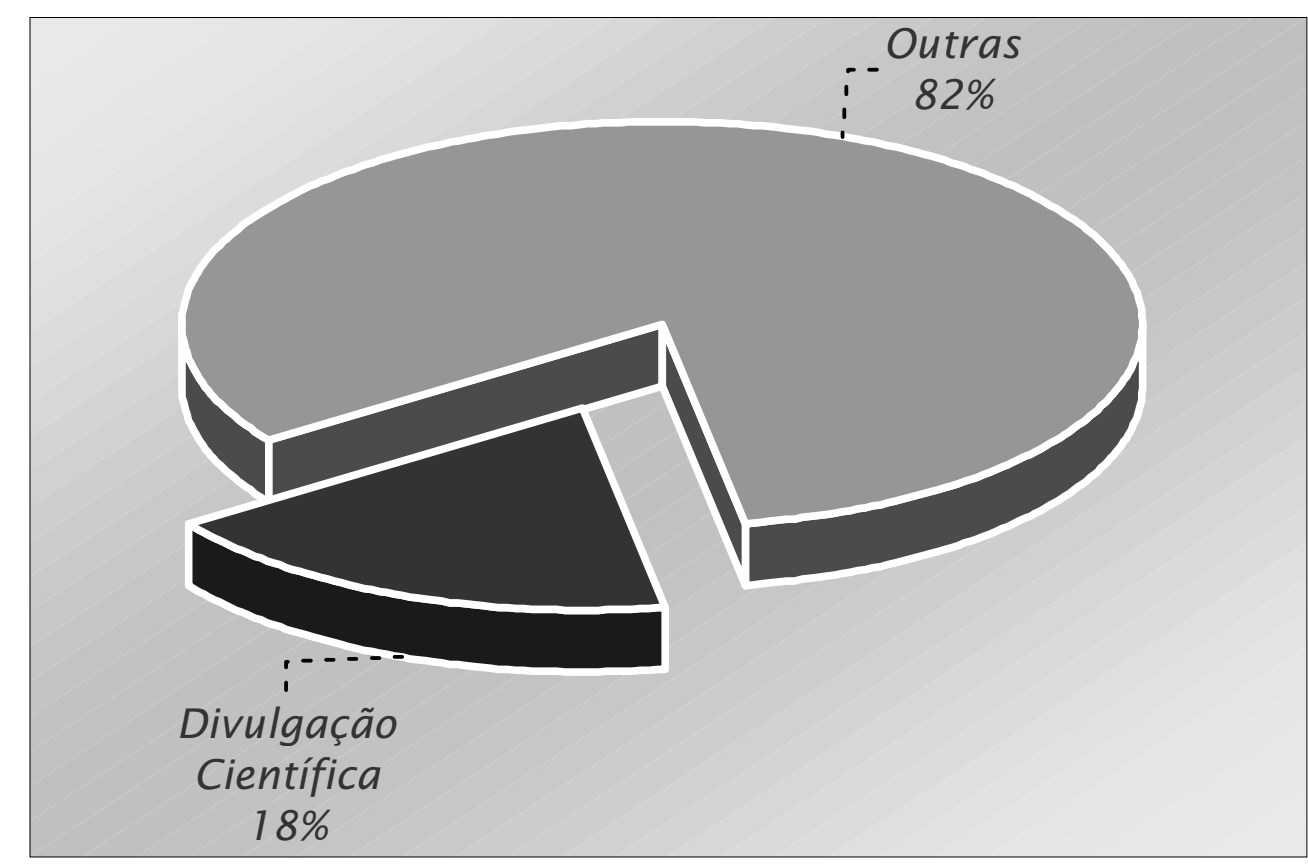

Gráfico 1 - Incidência dos textos da esfera da divulgação científica nas coletâneas de LDP (PNLD/2005).

Os principais gêneros da esfera da divulgação científica que se verificaram foram justamente os artigos, verbetes e reportagens e, numa incidência menor, os gráficos e epígrafes. Já da esfera escolar, os gêneros mais freqüentes são os textos didáticos e notas biográficas elaborados

\footnotetext{
15 “O Programa Nacional do Livro Didático (PNLD) é uma iniciativa do Ministério da Educação (MEC), cujos objetivos básicos são a aquisição e a distribuição, universal e gratuita, de livros didáticos para os alunos das escolas públicas do ensino fundamental brasileiro" (BATISTA, 2003, PP. 25-26).

${ }^{16}$ Para uma visão mais detalhada deste tipo de estudo, ver Rojo (2007, no prelo), onde analisamos as coletâneas de textos dos LDP destinados a alunos de $1^{\mathrm{a}}$ a $4^{\mathrm{a}}$ séries do EF que integraram os PNLD/2004 e 2007.
} 
pelos autores dos $\mathrm{LD}$ e, com menor incidência, resumos, glossários e definições. Os Gráficos 2 e 3 exibem os dados.

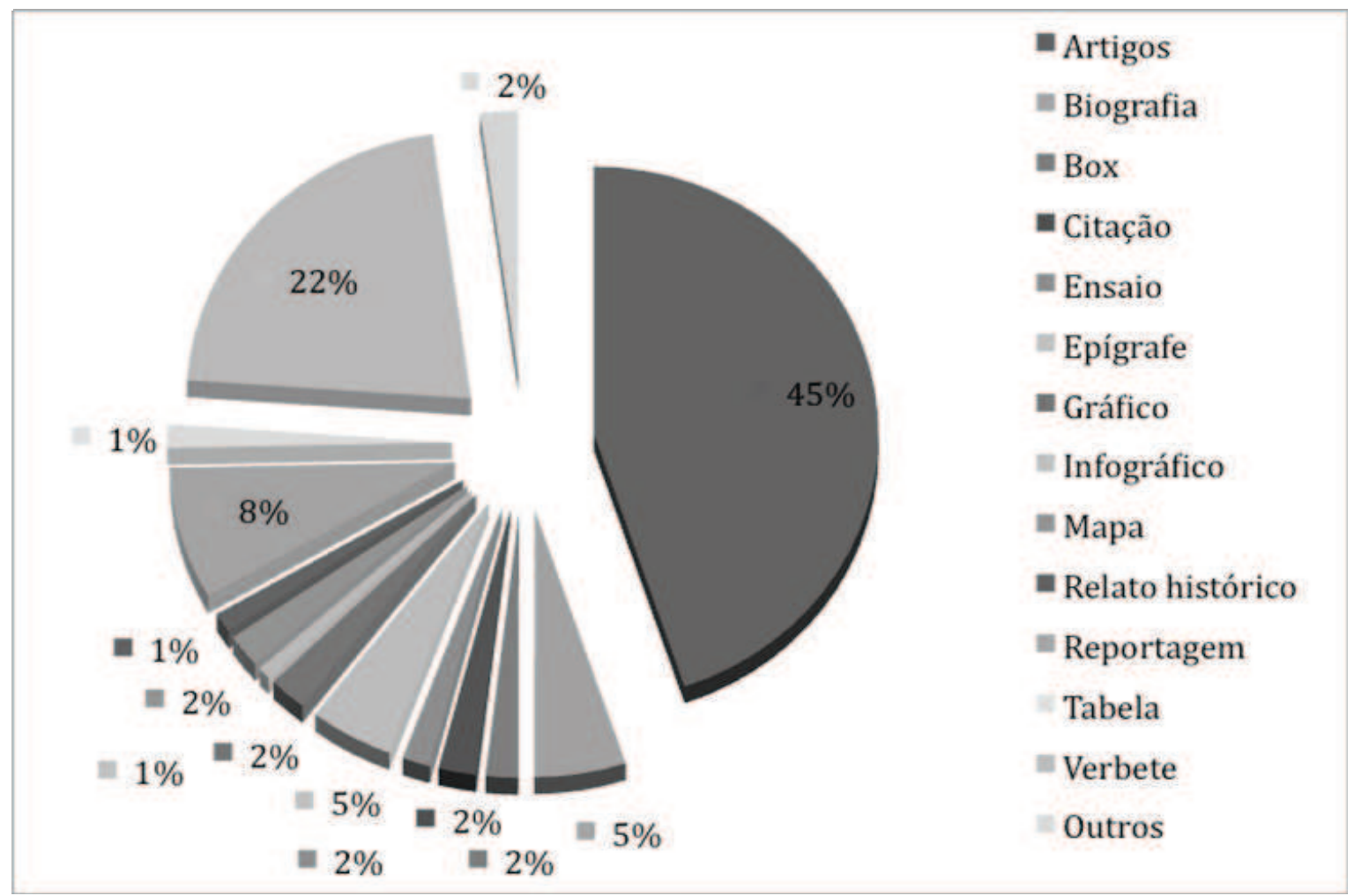

Gráfico 2 - Textos em gêneros da divulgação científica ( $\mathrm{n}=1615)$.

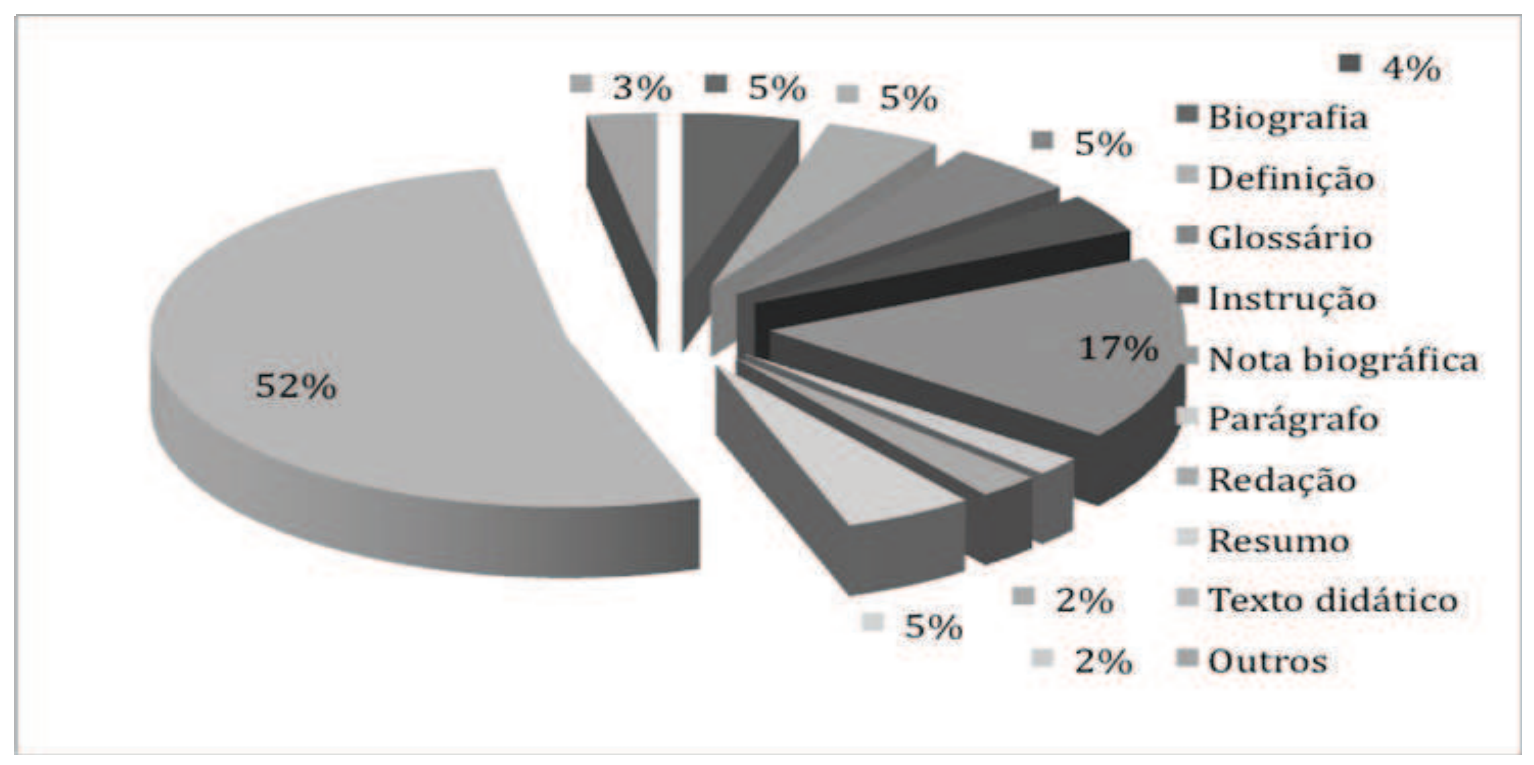

Gráfico 3 - Textos em gêneros escolares $(\mathrm{n}=873)$.

Note-se que nos textos didáticos, a multimodalidade ou multissemiose está ausente: estes se resumem a textos verbais. No caso 
dos textos da divulgação científica, possivelmente devido à exigência da avaliação do PNLD de que a reprodução dos textos respeite sua forma de composição em seu suporte de origem, aparecem textos híbridos e multissemióticos, como gráficos, tabelas, mapas e infográficos, que podem estar ou não integrando ou intercalando-se em outros gêneros, como artigos e reportagens. Mas seu percentual é mínimo: $2 \%$ de mapas e gráficos e 1\% de tabelas e infográficos. Estas escolhas para a coletânea já prenunciam uma pequena preocupação com os letramentos multissemióticos, tão importantes na esfera de divulgação da ciência.

Presentes, portanto, em um quinto dos textos dos manuais didáticos de Português e constitutivos dos textos dos LD de outras disciplinas do EF, os gêneros da divulgação científica integram intermitentemente as práticas/eventos de letramento escolares, embora raramente sejam abordados como objetos de estudo ou de (re)produção. Eles circulam nas salas de aula e são apropriados pelos alunos numa situação de "imersão" nos discursos da interação de sala de aula, numa situação não reflexiva de uso para outras finalidades, em geral ligadas à construção dos conhecimentos e conceitos disciplinares. ${ }^{17}$ Isto é, como ferramentas para o ensino de outros conteúdos.

Em pesquisa realizada sobre aulas de escola pública de São Paulo de todas as disciplinas das séries do EF pudemos verificar alguns dos mecanismos desse processo de apropriação que se dá nos eventos de letramento de sala de aula que envolvem textos de divulgação científica. $18 \mathrm{O}$ trecho de aula que se segue ilustra o processo. ${ }^{19}$

Pr.: Hoje a aula é sobre o quê? Formação do...

Al.: [solo.

Pr.: Como é formado o solo?

17 O tratamento didático dado a um conteúdo curricular é de imersão ou vivencial quando investe preferencialmente na idéia de que o aluno deve aprendê-lo vivenciando situações escolares em que esse conteúdo esteja diretamente envolvido. É o que se verifica, por exemplo, em atividades que apostam na idéia de que "é lendo que se aprende a ler".

18 Trata-se do Projeto FAPESP de Pesquisa Aplicada dentro da linha de fomento Melhoria do Ensino Público no Estado de São Paulo (MEP-FAPESP) de título Práticas de Linguagem no Ensino Fundamental: Circulação e apropriação dos gêneros do discurso e a construção do conbecimento, realizada entre 1999 e 2001.

19 Aula de Ciências documentada em 28/05/1999 na $3^{\text {a }}$ série. A professora L. e seus 36 alunos estudam sobre a composição do solo. 
Al.: Solo e rocha...

Pr.: O solo é formado de argila, que mais?

Als.: Areia, humo...

Pr.: Humo e...

Als.: [calcário!

Pr.: Calcário. Gente, argila, ou seja, barro (mostra com a mão um pouco de barro), certo? Areia todo mundo sabe / / Areia está aqui / dentro, nós vamos fazer experiência e depois vocês vão/ver. Bom / e o cal-cário, certo? Essa é a parte da / formação do...

Als.:

[solo.

Pr.: Veja, e depois do solo, o que que eu vou ter?

Als.: O subsolo.

Pr.: Subsolo. Nós vamos estudar primeiro a parte do...solo.

Als.:

[solo.

Pr.: Que é a parte arenoso, a argila e o cal...

Als.:

[...cário.

Pr.:...e o humífero; e depois nós vamos ver que realmente é o que está escrito aí no livro ${ }^{20}$ se é permeável, e se não é permeável, certo?

Als.: Certo!

Pr.: Tá, então, olhando aí no livro. A imagem de solo primeira é qual? Solo arenoso, o que tem bastante no solo arenoso?

$[\ldots]$

Pr.: Como é esse tipo de solo? Ele é...

Al.: Seco.

Pr.: Seco. Ele é seco. E, outra coisa, vamos ver, testando// eu tenho nessa garrafa (mostra uma garrafa)// Isso é um copinho de

${ }^{20}$ Livro: "Rosa dos Ventos" Ciências Naturais, Emmanuel Cavalcanti de Oliveira \& Maria da Penha Gonçalves, Editora Moderna.

ROJO - O letramento escolar e os textos da divulgação científica... 
plástico, algodão e areia/ então/ nós vamos jogar água pra ver o que que acontece nesse tipo de solo.// Vocês vão me dizer o que, o que acontece? (pega uma garrafa com água e começa a pôr água) Eu tô jogando a água, certo?

Als.: Certo.

(levanta a garrafa cortada com a areia e o copinho embaixo mostrando aos alunos)

Als.: Ela desce, a água desce muito rápido.

Pr.: Muito rápido. Deixa a água passar com facili...

Als.:

[dade.

Pr.: Então/ eu digo que esse solo é per...

Als.:

[meável.

Pr.: Permeável, porque deixa...

Als.:

[a água passar com facilidade.

Este trecho de aula mostra o papel que o verbete formação do solo, presente no texto do livro didático, tem no evento de letramento. De certo modo, a professora ensina aos alunos um outro modo de falar, contrapondo léxico cotidiano e linguagem especializada (barro/argila, água que desce muito rápido/permeável). Por meio de revozeamentos constantes e de um estilo docente de autoridade, a professora leva seus alunos a verticalmente (re)construírem no diálogo de sala de aula o texto monologal do verbete ("O solo é formado de argila, areia, humo e calcário. ${ }^{21} \mathrm{O}$ primeiro tipo de solo é o solo arenoso, que não é bom para

\footnotetext{
${ }^{21}$ Bakhtin (1953, p. 142) aponta a palavra autoritária como um estilo de recepção dos discursos que leva a tomar o discurso do autor como um monumento intocável, que deve ser aceito, assimilado e repetido (no caso em questão, o discurso do autor do LD). Diz Bakhtin: "o ensino das disciplinas verbais conhece duas modalidades básicas escolares de transmissão que assimila o [discurso de] outrem (do texto, das regras, dos exemplos): 'de cor' e 'com suas próprias palavras'. [...] O objetivo da assimilação da palavra de outrem adquire um sentido ainda mais profundo e mais importante no processo de formação ideológica do homem, no sentido exato do termo. Aqui, a palavra de outrem se apresenta não mais na qualidade de informações, indicações, regras, modelos etc., - ela procura definir as próprias bases de nossa atitude ideológica em relação ao mundo e de nosso comportamento, ela surge aqui como a palavra autoritária e como a palavra internamente persuasiva".
} 
o plantio, pois é seco e permeável, deixando a água passar com facilidade"). O texto e as imagens do LD ancoram toda a interação, que é constantemente referida a eles, articulando oralmente o que está impresso no papel.

A professora L. é sensível às dificuldades com o vocabulário específico (linguagem especializada) buscando ajustá-lo e contrapô-lo ao vocabulário cotidiano dos alunos e exemplificar concretamente certos conceitos, como o de permeabilidade. Este estilo de aulas foi recorrente nas 57 aulas documentadas, especialmente naquelas mais voltadas para conteúdos (Gramática, História, Geografia e Ciências) e não para procedimentos (como ocorre nas aulas de leitura, produção de textos e cálculo, por exemplo, em Português e Matemática).

A recorrência desses eventos de letramento escolar e a presença de textos de divulgação científica nos livros texto levam a uma apropriação desses gêneros por parte dos alunos que pode ser verificada nos seminários (exposições orais) que foram bastante solicitados pelos professores de Ciências, História e Geografia, nas $7^{\mathrm{a}}$ e $8^{\mathrm{a}}$ séries. As aulas expositivas sob controle dos alunos acabaram demonstrando que houve (ou ainda não, completamente) construção de gêneros e de conhecimentos específicos visados pelas áreas. ${ }^{22}$ É o que passaremos a analisar.

Apresentamos trechos de três das aulas documentadas em que grupos de alunos, sob a supervisão do professor, apresentavam seminários (exposições orais) sobre "conteúdos novos" ao restante da turma. Portanto, todas elas atendiam à necessidade de transmitir conhecimentos (ensinar) e todas se constituíram em exposições orais majoritariamente monologais. Trata-se de: (a) um seminário sobre o sistema urinário, em Ciências, na $7^{\mathrm{a}}$ série; (b) um seminário sobre a independência dos Estados Unidos, em História, também na $7^{\mathrm{a}}$ série; e (c) um seminário sobre a hidrografia da África, em Geografia, na $8^{a}$ série.

Um seminário, embora tenha uma situação de produção própria, em que o aluno encontra-se na posição de "especialista" (DOLZ, SCHNEUWLY; DE PIETRO; ZAHND, 1998) e passa a ter uma

\footnotetext{
${ }^{22}$ Essas aulas de seminários, nessa escola, podem ser interpretadas como "prática de ensino", pois se tratava de tematizar "conteúdos novos" para a turma e não conteúdos já explorados anteriormente pelo professor.
}

ROJO - O letramento escolar e os textos da divulgação científica... 
posição assimétrica em relação aos outros alunos - o que acarreta formas composicionais e estilo próprios - compartilha também das formas composicionais da aula expositiva - e dos gêneros da divulgação científica a ela hibridizados ou intercalados -, por outros aspectos da situação social de produção deste gênero (finalidade: transmissão de saberes escolares). Trata-se, portanto, de gênero secundário do discurso, monologal, mais ligado às formas escritas (léxico, formas lingüísticas), com ancoragem autônoma e disjunta.

Este é justamente o aspecto mais interessante dos três seminários sob análise. Dentre eles, somente o de Ciências preenche estas expectativas, pois o que é apresentado pela aluna é um texto "transmitido de cor". O de História é exposto a partir de formas lingüísticas muito aproximadas da linguagem oral informal, mais dialogal e selecionando léxico cotidiano e não científico. O de Geografia funciona ora de uma maneira, ora de outra. Comparem-se os três exemplos abaixo:

\section{Seminário de Ciências:}

Al1: Os rins são dois órgãos// Têm a forma de um feijão e a cor $[\mathrm{SI}]^{23}$ cinza. Ele está localizado abaixo do diafragma, atrás do fígado e do estômago. Cada um pesa aproximadamente 160 gramas. $\mathrm{O}$ sangue $[\mathrm{S}]$ várias artérias $[\mathrm{S}]$ também significam que se formam dois tipos de capilares. Capilares comuns, que alimentam os tecidos das células nos rins e capilares [SI] chamados bromeros, de onde sai o fluido filtrado dos rins. O sangue que sai do rim é reunido em $[\mathrm{SI}]$ que se desembocam na veia renal a qual leva o sangue $[\mathrm{SI}] /$ de um minuto para o outro passa um litro de sangue em cada rim. O rim é formado pela recepção [SI] filtradores, que tem o nome de néfron. Cada rim tem cerca de um milhão de néfrons. O néfron é um tubinho que se inicia pela cápsula de bromo que envolve o bromero, realiza curvas formando um "b", chamada de alça de Engel, e continua a fazer curvas. Termina desembocando em um tubo mais grosso que $[\mathrm{SI}]$ a urina saindo de vários néfrons vizinhos. Quando o sangue vai percorrendo lentamente os capilares do bromero [SI]/ a água sai junto com vitaminas, aminoácidos, uréia e ácido úrico

${ }^{23}[\mathrm{SI}]$ - segmento ininteligível. 
[SI] através de uma parede, mas as proteínas do plasma não. Esses fluidos que saem do bromero, enchem a cavidade da cápsula de bromos/ [SI] e corre se deslocando através do tubo renal. O fluido vai caminhando pelo tubo e percorre a alça de Engel. Várias substâncias ruins saem dele e retornam ao sangue, penetram nos capilares e ficam ao redor. Assim [SI aminoácidos, as vitaminas e outras substâncias, preciosas para o organismo. A uréia sai e outras substâncias tóxicas ficam no fluido e deslocamse através do tubo. Depois de passar na alça de Engel, o fluido pode ser chamado de urina. Esse recipiente [SI] mínima quantidade de resíduos e controla a composição sanguínea. Se houver substância que impeçam o sangue elas serão eliminadas, mesmo que sejam úteis. Acabou. [...]

\section{Seminário de História:}

Al1: Ó, as colônias, elas eram norte-americanas, né? Então, elas eram norte-americanas/ e elas eram atípicas/ e por isso elas eram diferentes de muitas outras $[\mathrm{SI}]$ coloniais. E a Inglaterra [SI] colônias, mas ela nem ligava, ela achava assim, que, sei lá/ não tinha valor, assim, não tinha aproveitamento. Então, a Inglaterra nem ligava. Então, em 1763, a Inglaterra tava em guerra com a França. Então/ em 1763 acabou a guerra da Inglaterra e da França. A Inglaterra ganhou. Só que, o que aconteceu? Ela ganhou a guerra. Mas ela perdeu muitas coisas, muitas riquezas/ ela perdeu. E por isso ela começou a ter dificuldades financeiras. $\mathrm{E}$ os norte-americanos, que eram os donos das treze colônias, não tinham, eles diziam que não tinham representantes no parlamento. Então, o que aconteceu? E não tinham que, assim, cumprir regras. Eles não tinham regras. O que eles queriam fazer eles fazia, o que dava na cabeça eles fazia./ E aí o parlamento/ ele decidiu que/ ele retirou o imposto/ ninguém mais precisava pagar imposto. E decidiu que só as Índias Orientais podiam vender o chá. Aí os navios ingleses chegaram no porto de Boston. Quando eles chegaram, os norte-americanos ficaram assim, sabe, ficaram nervosos e assaltaram o navio. Aí/ eles foram e roubaram todos os chás, roubaram todo o chá, e jogaram tudo no mar, e, aí, os ingleses, né? Que eles roubaram chá dos ingleses, né? Os norte-americanos. Aí/ os ingleses, ficaram com raiva, né? Eles levaram o chá deles. Aí eles foram e inventaram assim, leis absurdas. [...]

ROJO - O letramento escolar e os textos da divulgação científica... 


\section{Seminário de Geografia:}

Al1.: Pra diferenciar, né? // É ... a hidrografia do... da África é bastante vasta/ e tem é// os rios principais que... (aponta para o cartaz) é...

Al.: [É o quê?

Al2: É cheia de rios!

Al1: E também tem o rio que atravessa a.../ que é o Nilo/ que tem base na agricultura... Ele atravessa o Saara/ ajuda bastante na/ economia/ porque ele é base pra muitas coisas, é... Agricultura, pesca, e quando eles tão plantando tem uma época que o Nilo enche/ aí/ depois/ ele abaixa de novo/ aí fica um... um musgo lá chamado / é... // Ail Não sei o nome... Húmus/ aí/ ele faz o papel de fertilizar as plantas/ aí/ vai crescendo mais rápido e aí a produção aumenta... Fala você. [...]

Nos exemplos, vemos que o seminário de Ciências, aparentemente, realiza mais perfeitamente esta construção de gêneros da divulgação científica - isto é, o seminário é realizado de maneira mais aproximada ao verbete, que é seu gênero de origem. Por outro lado, da perspectiva da efetiva apropriação, seja do gênero, seja do conhecimento visado, temos mais a dizer sobre os outros dois seminários, já que, no de Ciências, a aluna parece ter memorizado o texto de origem (não necessariamente com compreensão) e ter tomado o texto original de base como apoio a sua realização oral, sem que isso testemunhe, necessariamente, aprendizagem ou apropriação.

No caso do seminário de História, há fenômenos bastante interessantes. Em primeiro lugar, há um bibridismo de estilos e de vozes nos enunciados da aluna. ${ }^{24} \mathrm{~A}$ aluna oscila, em termos de estilo, entre um vocabulário cotidiano e a linguagem especializada ("ó, então,

${ }^{24}$ Para Bakhtin (1935, p. 110), o bibridismo ocorre quando o enunciado "segundo índices gramaticais (sintáticos) e composicionais, pertence a um único falante, mas onde, na realidade, estão confundidos dois enunciados, dois modos de falar, dois estilos, duas 'linguagens', duas perspectivas semânticas e axiológicas. [...] Entre esses enunciados, estilos, linguagens, perspectivas, não há nenhuma fronteira formal, composicional e sintática: a divisão das vozes e das linguagens ocorre nos limites de um único conjunto sintático, freqüentemente nos limites de uma proposição simples; freqüentemente também, um mesmo discurso pertence simultaneamente às duas línguas, às duas perspectivas que se cruzam numa construção híbrida, e, por conseguinte, tem dois sentidos divergentes, dois tons". 
diferentes/atípicas), formas sintáticas mais complexas e outras própria da enunciação oral ("Ó, as colônias, elas eram norte-americanas, né? Então, elas eram norte-americanas" / "elas eram atípicas/ e por isso elas eram diferentes de muitas outras [SI] coloniais") e, em termos de vozes, entre uma compreensão ativa de senso comum do fato histórico - que comentaremos adiante - e o revozeamento do texto lido, em que o fato é visto do ponto de vista histórico-social e político ("Aí/ eles foram e roubaram todos os chás, roubaram todo o chá, e jogaram tudo no mar, e, aí, os ingleses, né? Que eles roubaram chá dos ingleses, né? Os norte-americanos. Aí os ingleses, ficaram com raiva, né?"/"os norte-americanos, que eram os donos das treze colônias, não tinham, eles diziam que não tinham representantes no parlamento").

Essa maneira de enunciar ao mesmo tempo nos dá mais clareza a respeito do conhecimento apropriado e de seus mecanismos: "atípica" já é sinônimo estabilizado de "diferentes de muitas outras"; a aluna percebe bem que, embora a Inglaterra tenha ganhado a guerra, ela teve perdas econômicas e comerciais, base sobre a qual se estabeleceu o espaço de negociação política dos norte-americanos. Percebe também o mecanismo de retaliação adotado tanto pela Inglaterra (comercial: restrições ao acesso aos produtos), como pelos norte-americanos (revoltoso: boicote à importação). Só que, o mesmo discurso (linguagem social, perspectiva, voz) cotidiano que nos faz ver o que a aluna entendeu, faz-nos suspeitar do que ela não se apropriou. O enunciado "Aí/ eles foram e roubaram todos os chás, roubaram todo o chá, e jogaram tudo no mar, e, aí, os ingleses, né? Que eles roubaram chá dos ingleses, né? Os norteamericanos. Aí/ os ingleses, ficaram com raiva, né? Eles levaram o chá deles" sugere que a aluna não compreende bem este processo de insurreição como político-econômico, mas como cotidiano. Faz pensar em americanos jogando saquinhos de chá Lipton Tea (note-se o plural "os chás") no Atlântico e não num mecanismo de retaliação econômica. "Raiva" e "nervosismo" são temas cotidianos e privados que não cabem em instâncias públicas. Note-se que essa hibridização do discurso cotidiano e científico, do discurso da História e do senso comum, pode também ser entendida como uma manifestação mestiça da cultura local da aluna e da cultura escolar/oficial. Neste sentido, pode ser vista como uma manifestação de multiletramentos (híbridos). O problema é que, ao invés da escola detectar essa "mestiçagem" e sobre ela trabalhar, ela a 
toma como erro ou como "dificuldade com o português padrão" simplesmente, numa perspectiva normativa e prescritiva. ${ }^{25}$

Já o seminário de Geografia, intermediário aos dois anteriores, faz ver um processo de apropriação mais avançado do que o do seminário de História, na medida em que o(a) aluno(a) tem controle metacognitivo sobre o que sabe ou não sabe (hesitações e o enunciado "Ai! Não sei o nome... Húmus/ aí!/"), ou seja, sobre o que pertence a uma linguagem social e gênero ou a outros. Este(a) aluno(a) sabe que (ainda) não sabe.

Note-se, ainda, que somente no seminário de Geografia os alunos fazem recurso a suportes em outras semioses (cartaz com mapa elaborado por eles). Nos outros casos, mesmo quando muito necessário, como no caso do seminário de Ciências, os alunos não se utilizam desses recursos (mapas, mapa do corpo humano), embora disponíveis na escola, restringindo-se à fala e ao texto escrito a mão e copiado do LD que consultam e que a suporta. Mais uma vez, isto indica que o valor dos letramentos multissemióticos ou multimodais não é ainda algo reconhecido e enfatizado pela escola.

Finalmente, o que se nota nos discursos dos seminários dos alunos é um estilo autoritário, repetidor do texto retirado do LD - que varia do "texto de cor" ao texto revozeado -, mais do que um estilo internamente persuasivo em que a voz do aluno se hibridiza ao discurso de origem, permitindo ecoar suas apreciações de valor; isso somente acontece no seminário de História, no qual a aluna deixa entrever suas apreciações (ela nem ligava, ela achava assim, que, sei lál não tinha valor, assim, não tinha aproveitamento, $O$ que eles queriam fazer eles fazia, o que dava na cabeça eles faria, por exemplo). ${ }^{26}$ Esse estilo preferencial pode estar indiciando um certo tipo de trato escolar dos textos bastante distante dos letramentos críticos e protagonistas que discutimos no início deste texto.

\footnotetext{
${ }^{25}$ Avaliação emitida pela professora S.

${ }^{26}$ Segundo Bakhtin (1935, p. 143-144), "a palavra autoritária exige de nós o reconhecimento e a assimilação, ela se impõe a nós independentemente do grau de sua persuasão interior no que nos diz respeito; nós já a encontramos unida à autoridade [...] O discurso autoritário exige nosso reconhecimento incondicional, e não absolutamente uma compreensão e assimilação livre em nossas próprias palavras." Este último estilo de compreensão ativa, que pode ser valorativa e crítica, é o que o autor denomina "palavra internamente persuasiva".
} 


\title{
4 DECORRÊNCIAS PARA A REFLEXÃO DO(A) PROFES- $\operatorname{SOR}(\mathrm{A})$
}

\begin{abstract}
Vimos, ao longo deste artigo, que a sociedade contemporânea apresenta demandas de letramentos múltiplos, críticos e multissemióticos. Vimos também que os letramentos na escola, dominantes e institucionais, embora pudessem e devessem fazê-lo, resistem a encampar essas demandas, por um lado, reduzindo a multiplicidade de práticas o que é testemunhado pela presença massiva, em livros escolares e nas salas de aula, mesmo em LDP, de textos em gêneros da divulgação científica.
\end{abstract}

Abordamos esses gêneros e seus temas, estilos e formas de composição a partir da parcial reconstituição de sua história e das características das situações de produção desses enunciados na esfera da divulgação científica. Se assim fossem tratados na escola, seria possibilitada uma recepção crítica dos discursos da ciência, assim como um domínio e apropriação de suas propriedades formais, composicionais e temáticas. No entanto, nossos dados apontam para uma abordagem pouco crítica (ou internamente persuasiva), privilegiando-se um estilo autoritário de recepção dos discursos, e uma apropriação desses gêneros por imersão nas práticas e eventos de letramento escolar, que os naturalizam, reificam e simplificam. Por exemplo, as características multissemióticas desses textos não são enfocadas, havendo uma redução ao verbal (oral). Isso torna o processo de apropriação por parte do aluno, complexo, com idas e vindas, solitário e de certa maneira indisciplinado.

Cremos que uma sensibilização do professor para estes processos discursivos será capaz de levá-lo a avaliar mais adequadamente o processo de apropriação de seus alunos, sem necessidade de avaliação formal: apenas com a construção de uma sensibilidade "antenada" para seu próprio discurso e para o discurso de seus alunos em sala de aula. Acreditamos também que uma abordagem mais clara e reflexiva dos gêneros em questão, que parta de suas circunstâncias de produção e de circulação para verificar seus efeitos nas formas, linguagens e temas, poderia levar a uma leitura crítica desses textos, levando o aluno a com eles dialogar.

ROJO - O letramento escolar e os textos da divulgação científica... 
Do ponto de vista do ensino-aprendizagem e da apropriação do conhecimento, não se trata de ser meramente dialogal ou monologal, mas dialógico - no sentido bakhtiniano -, ou seja, que, para além do gênero, estão em questão as condições de recepção e de produção dos textos ou discursos de sala de aula. De certa maneira, estão em questão principalmente os estilos (autoritário ou internamente persuasivo) dos enunciados no gênero, do texto didático, do professor e dos alunos.

\section{REFERÊNCIAS}

BAKHTIN, M. M. Os gêneros do discurso. In: verbal. São Paulo: Martins Fontes, 1992 [1953]. p. 277-326.

. Estética da criação

. O discurso no romance. In: . Questões de literatura e de estética: a teoria do romance. São Paulo: Hucitec, 1988 [1935]. p. 71-210. BARTON, D. Preface: Literacy events and literacy practices. In: HAMILTON, M.; IVANIC, R. Worlds of literacy. Clevedon: Multilingual Matters, 1994.

; HAMILTON, M. Local literacies: reading and writing in one community. London: Routledge, 1998.

BATISTA, A. A. G. A avaliação dos livros didáticos: para entender o Programa Nacional do Livro Didático (PNLD). In: ROJO, R. H. R.; BATISTA, A. A. G. (Orgs.). Livro didático de Língua Portuguesa, letramento e cultura da escrita. Campinas: Mercado de Letras, 2003. p. 25-68.

BEAUDOUIN, V. De la publication à la conversation: lecture et écriture électroniques. Réseaux, 2002/6, n. 119, pp. 199-225. Disponible em: http://www.cairn.info/article.php?ID_REVUE=RES\&ID_NUMPUBLIE =RES_116\&ID_ARTICLE=RES_116_0199. Acesso em: 26 março 2007.

CHARTIER, R. A aventura do livro: do leitor ao navegador. São Paulo: EDUNESP, 1998 [texto original publicado por Les Editions Textuel em 1997].

DE CERTEAU, M. A invenção do cotidiano 1: artes de fazer. 5. ed. Petrópolis: Vozes, 1994 [1980].

DIDEROT, D.; D'ALAMBERT, J. R. Encyclopédie ou dictionnaire raisonné des sciences, des arts et des métiers, par une société de gens de 
lettres. Paris: [s.n.], 1751-1772. Disponível em: http://www.educ.fc.ul.pt/ hyper/encyclopedie.htm. Acesso em 5 maio 2008.

DOLZ, J.; SCHNEUWLY, B.; DE PIETRO, J.-F.; ZAHND, G. A exposição oral. In: SCHNEUWLY, B.; DOLZ, J.; e colaboradores. Gêneros orais e escritos na escola. Organização e tradução de R. H. R. Rojo e G. S. Cordeiro. Campinas: Mercado de Letras, 2004 [1998]. p. 215-246.

GEE, J. P. Social linguistics and literacies: ideology in discourses. London; Briston: Taylor \& Francis, 1996.

GRILLO, S. V. C. Divulgação científica na esfera midiática. Intercâmbio, n. 15, 2006. Disponível em: www.pucsp.br/pos/lael/ intercambio/pdf/grillo.pdf.

Acesso em: 30 agosto 2007.

HAMILTON, M. Sustainable literacies and the ecology of lifelong learning. In: HARRISON, R. R. F.; HANSON, A.; CLARKE, J. (Orgs.). Supporting lifelong learning. V. 1: Perspectives on learning. London: Routledge; Open University Press, 2002. p. 176-187.

HEATH, S. B. Ways with words: language, life and work in communities and classrooms. Cambridge: Cambridge University Press, 1983.

KLEIMAN, A. B. Modelos de letramento e as práticas de alfabetização na escola. In: KLEIMAN, A. B. (Org.). Os significados do letramento: uma nova perspectiva sobre a prática social da escrita. Campinas: Mercado de Letras, 1995. p. 15-64.

Ação e mudança na sala de aula: uma pesquisa sobre letramento e interação. In: ROJO, R. H. R. (Org.). Alfabetização e letramento: perspectivas lingüísticas. Campinas: Mercado de Letras, 1998.

LARROUSE, P. Grand dictionnaire universel du XIX ${ }^{\mathrm{eme}}$ Siècle, XXV. Paris: [s.n.], 1866. Disponível em: www.educ.fc.ul.pt/hyper/enciclopedia/cap2p5/ obracolec.htm. Acesso em: 5 maio 2008.

MOITA-LOPES, L. P.; ROJO, R. H. R. Linguagens, códigos e suas tecnologias. In: BRASIL. Ministério da Educação. Orientações Curriculares de Ensino Médio. Brasília, DF: MEC/SEB/DPEM, 2004. p. 14-56.

PRINSLOO, M.; BREIER, M. (Orgs.). The social uses of literacy: theory and practice in contemporary South Africa. Philadelphia: John Benjamins, 1996.

RABELAIS, F. Gargantua e Pantagruel. Belo Horizonte: Itatiaia, 2003.

ROJO, R. H. R. Coletâneas de textos nos livros didáticos de Língua Portuguesa: letramentos possíveis. In: COSTA VAL, M. G. (Org.). Alfabetização e

ROJO - O letramento escolar e os textos da divulgação científica... 
letramento: o que ensinam os livros didáticos? Belo Horizonte: Autêntica; CEALE, [2007, no prelo].

SOUZA SANTOS, B. Os processos da globalização. In: . (Org.). A globalização e as ciências sociais. São Paulo: Cortez, 2005. p. 25-102.

STREET, B. V. Literacy in theory and practice. Cambridge: Cambridge University Press, 1984.

Social literacies: critical approaches to literacy in development, ethnography and education. London, New York: Longman, 1995.

What's "new" in new literacy studies? Critical approaches to literacy in theory and practice. Current Issues in Comparative Education, v. 5, n. 2, p. 77-91, 2003.

Recebido em 16/08/08. Aprovado em 23/09/08.

Title: School literacy and pop science texts - the appropriation of genres at school Author: Roxane Rojo

Abstract: In this paper we define school literacy based on the approach of multiple and situated literacies (multiliteracies) and, from a Bakhtinian perspective, we briefly describe some pop science genres (dictionary/encyclopedia entries, papers, reportages) that are frequently taught. Viewing the process of genre appropriation as an important aspect of school literacy practices and processes, in the second part of the paper we analyze how the process appropriation of pop science genres occurs in classrooms, examining expositions (seminars) of secondary school students (7th and 8th grades). The results show that pop science texts, although very frequent in school textbooks and discursive practices, are not effectively approached and their appropriation by the students occurs by language immersion, which raises difficulties specifically related to specialized languages.

Keywords: school literacy; genres; pop science.

Titre: La littératie écolière et les textes de vulgarisation scientifique - l'appropriation des genres de discours à l'école

Auteur: Roxane Rojo

Résumé: Dans cet essai on définit la littératie écolière dans la perspective des littératies multiples et situées et, à partir d'une discussion sur les textes de vugarisation scientifique, qui se caractérisent d'une manière abrégée, dans la perspective bakhtinienne, quelques genres discursifs de la divulgation scientifique employés à l'école (notes, articles, reportages). En comprenant le procès d'appropriation de genres discursifs comme un aspect important des pratiques et des procès de littératie écolière, l'essai, dans sa deuxième partie, apporte une analyse de comment ce procès 


\section{2}

d'appropriation des genres de la vulgarisation se passe dans les salles de classe, à partir de séminaires réalisés par des élèves de l'Enseignement Fondamental II (EFII). Les résultats indiquent que, malgré la présence dans les livres et pratiques discursives écolières, les textes de vulgarisation scientifique ne sont pas effectivement abordés dans l'enseignement et leur appropriation se fait par immersion, posant surtout des problèmes par rapport aux langages spécialisés.

Mots-clés: littératie écolière; genre discursif; vulgarisation scientifique.

Título: La literacia escolar y los textos de la divulgación científica - la apropriación de los géneros de discurso en la escuela

Autor: Roxane Rojo

Resumen: En este ensayo se define literacia escolar en la perspectiva de lãs literacias múltiples y situadas y, a partir de una discusión sobre los textos de la divulgación científica, se caracterizan brevemente, en la perspectiva bakhtiniana, algunos de los géneros discursivos de la divulgación científica didactizados en la escuela (verbetes, artículos, reportajes). Entendiendo el proceso de apropriación de géneros discursivos como un aspecto importante de las prácticas y de los procesos de literacia escolar, el ensayo, en su segunda parte, trae un análisis de como este proceso de apropriación de los géneros de la divulgación científica se da en las aulas, a partir de seminarios realizados por alumnos de la Enseñanza Fundamental II (EFII). Los resultados indican que, aunque muy presentes en los libros y prácticas discursivas escolares, los textos de la divulgación científica no son efectivamente abordados en la enseñanza y su apropriación se hace por inmersión, colocando especialmente problemas en relación a los lenguajes especializados.

Palabras-clave: literacia escolar; género discursivo; divulgación científica.

ROJO - O letramento escolar e os textos da divulgação científica... 